\title{
Aspergillus niger $\beta$-galactosidase production by yeast in a continuous high cell density reactor
}

\author{
Lucília Domingues, Nelson Lima, José A. Teixeira* \\ Centro de Engenharia Biológica, Universidade do Minho, Campus de Gualtar, 4710-057 Braga, Portugal
}

Received 7 October 2003; received in revised form 25 March 2004; accepted 1 April 2004

\begin{abstract}
The continuous production of extracellular heterologous $\beta$-galactosidase by a recombinant flocculating Saccharomyces cerevisiae, expressing the lacA gene (coding for $\beta$-galactosidase) of Aspergillus niger was investigated. A continuous operation was run in a 6.51 airlift bioreactor with a concentric draft tube using lactose as substrate. Data on the operation with semi-synthetic medium with 50 and $100 \mathrm{~g} / \mathrm{l}$ initial lactose concentrations are presented. The best result for $\beta$-galactosidase productivity $-6.2 \times 10^{5} \mathrm{U} / 1 \mathrm{~h}$-was obtained for a system operating at $0.24 \mathrm{~h}^{-1}$ dilution rate and for a lactose concentration in the feed of $50 \mathrm{~g} / \mathrm{l}$. This value represents a 11 -fold increase in $\beta$-galactosidase productivity when compared to batch culture. Together with extracellular $\beta$-galactosidase production an ethanol productivity of $9 \mathrm{~g} / 1 \mathrm{~h}$ was obtained for the bioreactor fed with $50 \mathrm{~g} / \mathrm{l}$ initial lactose concentration at $0.45 \mathrm{~h}^{-1}$ dilution rate. In addition to $\beta$-galactosidase and ethanol production, this system allowed for complete lactose metabolism. The feasibility and advantages of using continuous high-cell-density systems operating with flocculent yeast cells for extracellular protein production is clearly shown.
\end{abstract}

(C) 2004 Elsevier Ltd. All rights reserved.

Keywords: $\beta$-Galactosidase production; Continuous heterologous protein production; Flocculation; Whey permeate fermentation; Recombinant yeast

\section{Introduction}

Principal among some enzymes that have important and growing applications is $\beta$-galactosidase [1]. This enzyme is mainly used to hydrolyse lactose into glucose and galactose. Problems with lactose fall within three main areas, health, food technology and environment and are behind the ongoing interest in $\beta$-galactosidase production. Concerning the health issue, lactose becomes a problem when there is insufficient intestinal $\beta$-galactosidase enzyme and lactose is passed into the blood, finally appearing in the urine and in the large intestine resulting in several disorders [2]. Lactose intolerant people are restricted to the lactose amount they can ingest daily. Because of these problems the reduction of the lactose content in milk and dairy products is of prime importance and the enzyme $\beta$-galactosidase is commercially used for this purpose $[3,4]$. From the food technology point of view, the high lactose content in non-fermented

* Corresponding author. Tel.: +351 253 604400; fax: +351253678986.

E-mail addresses: luciliad@deb.uminho.pt (L. Domingues), nelson@iec.uminho.pt (N. Lima), jateixeira@deb.uminho.pt (J.A. Teixeira). milk products such as ice-cream and condensed milk, can lead to excessive lactose crystallisation resulting in products with a mealy, sandy or gritty texture. Again, the use of $\beta$-galactosidase enzyme prior to the condensing operation can reduce the lactose content to a point where lactose is no longer a problem [2]. Moreover, glucose and galactose expand the use of lactose in food because of a marked increase in sweetness and solubility [5]. From the environmental point of view, lactose is associated with the high biochemical and chemical oxygen demand (BOD/COD) content of whey. With the ever-increasing market for whey protein concentrates (WPC), a lactose-rich stream is produced (permeate) with reduced economical value but still with a high pollutant load. Several alternatives exist for cheese whey/permeate treatment, $\beta$-galactosidase application certainly being one of these. $\beta$-Galactosidase can be employed directly to the cheese whey/permeate stream resulting in high sweetness syrups and used as additive in ice-creams, desserts, etc. [6]. Another alternative is to produce cheese with an enzymatic $\beta$-galactosidase treatment, resulting in cheese whey with low lactose content enabling its concentration and use as a food additive [7]. New applications for $\beta$-galactosidase enzyme such as in the recovery of biologically active oligosaccharides from milk have also been described in literature [8]. 
$\beta$-Galactosidase industrial production is hampered by the high costs associated with its production and purification. One way to improve the overall productivity of $\beta$-galactosidase fermentation system would be to use continuous high-cell-density systems. Among these, those that use flocculent cells are attractive due to its simplicity and low cost. In addition, as in any other fermentation process, the system overall productivity will be improved if a low cost substrate is used, as is the case of lactose [5].

We have previously described the construction of a flocculent Saccharomyces cerevisiae strain [9] for lactose fermentation and its application in a continuous high-cell-density bioreactor for cheese whey treatment with high ethanol productivity $[10,11]$. The contamination resistance of this system when operated at sufficiently high dilution rates was also shown [12]. In this work, we intend to show the applicability of continuous high-cell-density systems operated with flocculent yeast cells for extracellular $\beta$-galactosidase production. These systems have never been used for extracellular protein production before. For this purpose a flocculent $S$. cerevisiae strain secreting high levels of Aspergillus niger $\beta$-galactosidase was constructed and applied to a continuous high-cell-density bioreactor fed with lactose substrate. As $\beta$-galactosidase is secreted into the culture medium and cells are easily separated from the culture broth (due to its flocculence) the purification step is greatly simplified. Moreover, due to the higher biomass concentration occurring inside the bioreactor, higher $\beta$-galactosidase productivity is obtained for this system, allowing for a significant improvement in $\beta$-galactosidase fermentation process.

\section{Material and methods}

\subsection{Microorganism}

A recombinant S. cerevisiae NCYC869-A3/pVK1.1 flocculent strain expressing the lacA (coding for $\beta$-galactosidase) gene of $A$. niger under the $S$. cerevisiae $A D H 1$ promoter and terminator was used [13].

\subsection{Culture media}

The recombinant yeast was maintained at $4{ }^{\circ} \mathrm{C}$ on agar slants or at $-80^{\circ} \mathrm{C}$ in permanent culture of YNB selective medium having the following composition: $6.7 \mathrm{~g} / \mathrm{l}$ yeast nitrogen base (w/o amino acids), $20 \mathrm{~g} / \mathrm{l}$ lactose. The yeast was grown on semi-synthetic lactose medium (SSlactose) containing (g/l): $\mathrm{KH}_{2} \mathrm{PO}_{4} 5 ;\left(\mathrm{NH}_{4}\right)_{2} \mathrm{SO}_{4} 2 ; \mathrm{MgSO}_{4} .7 \mathrm{H}_{2} \mathrm{O} 0.4$; yeast extract 2.0 ; lactose 50 or 100 .

\subsection{Continuous-culture experiments}

An airlift bioreactor with a concentric draft tube made of Perspex with a working volume of 6.51 was used [10]. The regulation system allows for temperature control at $30 \pm 1{ }^{\circ} \mathrm{C}$, foam level control by addition of antifoam (Sigma A-5551) and $\mathrm{pH}$ control by automatic addition of ammonia with a set-point at $\mathrm{pH} 4.0 \pm 0.1$. The system was aerated with filtered air at a flow rate of $0.0800-1.0000 \pm 0.0002 \mathrm{vvm}$ (volume air per volume reactor per minute). The flow rate was controlled using a Hastings mass-flow controller. It is worth noting that an increase in the air-flow rate was needed when increasing dilution rate in order to prevent the bioreactor from stalling. Dilution rates were assayed between 0.1 and $0.45 \mathrm{~h}^{-1}$.

For start-up of the continuous culture, cells were grown in a 2-1 Erlenmeyer flask filled with 11 of culture medium, for $24 \mathrm{~h}$. The cell suspension was then aseptically transferred to the bioreactor, which was kept in batch operation for $24 \mathrm{~h}$ before switching on to continuous feeding.

\subsection{Analysis}

The cell concentration, i.e. biomass concentration, was estimated by a dry weight method. The dry weight cell concentration was determined by filtering the sample through $0.2-\mu \mathrm{m}$ filter paper and then dried at $105^{\circ} \mathrm{C}$ for $24 \mathrm{~h}$. Total reducing sugar concentration was determined by a dinitrosalicylic acid method [14]. Lactose, glucose, galactose and ethanol concentrations were determined by HPLC (PL Hi-Plex PB Column). The solvent used was ultra-pure water, at a flow rate of $0.6 \mathrm{ml} / \mathrm{min}$, while detection was effected with a refractive-index detector. Temperature was maintained at $80^{\circ} \mathrm{C}$. Cell viability was estimated by the vital methylene blue staining method and direct cell counting in a Neubauer chamber. The percentage of cells expressing $\beta$-galactosidase was monitored in YNB medium containing galactose as the carbon source and $\mathrm{X}$-gal as indicator of $\beta$-galactosidase activity.

\section{Results and discussion}

Different fermentation parameters measured during continuous operation at increasing dilution rates are represented in Fig. 1. Continuous operation was started at $0.1 \mathrm{~h}^{-1}$ dilution rate and increased stepwise (up to $0.45 \mathrm{~h}^{-1}$ ). At each dilution rate, five residence times were allowed to pass. Fermentation parameters (total reducing sugars, ethanol, biomass and $\beta$-galactosidase concentration) were measured and a new dilution rate applied.

Initially, the $\beta$-galactosidase extracellular production increased with the increase in the dilution rate, remained constant between 0.13 and $0.24 \mathrm{~h}^{-1}$ dilution rate, suffered an accentuated decrease for $0.3 \mathrm{~h}^{-1}$ dilution rate and stabilised for higher dilution rates. For dilution rates lower than $0.24 \mathrm{~h}^{-1}$ reducing sugar concentration was always smaller than $1 \mathrm{~g} / \mathrm{l}$. When increasing the dilution rate from 0.24 to $0.3 \mathrm{~h}^{-1}$, the reducing sugar concentration raised to $5 \mathrm{~g} / \mathrm{l}$ being this value kept at $0.4 \mathrm{~h}^{-1}$ dilution rate. At 


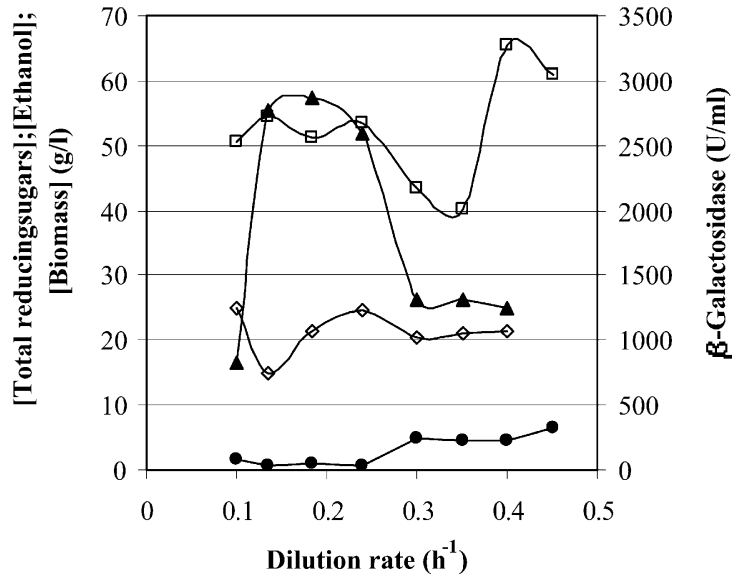

Fig. 1. Variation of biomass concentration inside the bioreactor ( $\square$ ), total reducing sugars $(\boldsymbol{O})$, ethanol $(\diamond)$ concentration and $\beta$-galactosidase activity $(\boldsymbol{\Delta})$ with dilution rate for continuous operation with SSlactose medium $(50 \mathrm{~g} / 1$ lactose).

higher dilution rates, a further increase in reducing sugar concentration was observed.

Cell viability was more than $90 \%$ during the entire operation period. For dilution rates lower than $0.24 \mathrm{~h}^{-1}$, the percentage of cells expressing $\beta$-galactosidase was more than $90 \%$, decreasing for higher dilution rates. As may be observed, a continuous decrease in extracellular $\beta$-galactosidase production (expressed as $\mathrm{U} / \mathrm{ml}$ or $\mathrm{U} / \mathrm{g}$ biomass) was obtained for higher dilution rates. The observed increase in the $\beta$-galactosidase activity for the lower dilution rates maybe due to an increase in the plasmid copy number attributed to continuous selection for cells with higher copy number [15] or to an increase in the efficiency of the secretion process [16]. As dilution rate was increased, biomass growth led to an increase in biomass accumulation inside the bioreactor with a simultaneous increase in $\beta$-galactosidase activity. This increase in extracellular $\beta$-galactosidase activity led to a more rapid lactose hydrolysis rate than the galactose and glucose metabolisation rate, allowing sugar accumulation in the culture medium. The existence of glucose and galactose sugars in the culture broth may induce the growth of cells that have lost the plasmid or may repress $\beta$-galactosidase production, decreasing the percentage of $\beta$-galactosidase producing cells. Up to a dilution rate of $0.3 \mathrm{~h}^{-1}$ the glucose and galactose concentration in the culture broth were less than $1 \mathrm{~g} / \mathrm{l}$, for $0.35 \mathrm{~h}^{-1}$ a $2.7 \mathrm{~g} / \mathrm{l}$ galactose concentration and $2.0 \mathrm{~g} / \mathrm{l}$ glucose were detected, while for $0.45 \mathrm{~h}^{-1}$ these values increased to 3.8 and $2.7 \mathrm{~g} / \mathrm{l}$, respectively. These data confirm the previous reasoning on the importance of the relative values of the glucose and galactose metabolisation rates and the rate of $\beta$-galactosidase production in the control of the percentage of $\beta$-galactosidase producing cells.

For $50 \mathrm{~g} / 1$ initial lactose concentration, this continuous high-cell-density system allowed for an 11-fold increase in $\beta$-galactosidase productivity when compared to batch system (Table 1).
Table 1

Comparison of maximum $\beta$-galactosidase productivity obtained with batch and continuous high-cell-density culture

\begin{tabular}{ll}
\hline $\begin{array}{l}\text { Fermentation } \\
\text { conditions }\end{array}$ & $\begin{array}{l}\text { Maximum } \beta \text {-galactosidase } \\
\text { productivity }(\mathrm{U} / \mathrm{h} \text { ) }\end{array}$ \\
\hline $\begin{array}{l}\text { Batch culture with SSlactose } \\
\text { medium }(5 \%)\end{array}$ & $5.9 \mathrm{E} 4$ \\
$\begin{array}{l}\text { Batch culture with SSlactose } \\
\text { medium (10\%) }\end{array}$ & $1.4 \mathrm{E} 5$ \\
$\begin{array}{l}\text { Continuous culture with SSlactose } \\
\text { medium }(5 \%) \text { at } 0.24 \mathrm{~h}^{-1}\end{array}$ & $6.2 \mathrm{E} 5$ \\
$\quad$ dilution rate & \\
Continuous culture with & \\
$\quad \begin{array}{l}\text { SSlactose medium }(10 \%) \text { at } \\
0.18 \mathrm{~h}^{-1} \text { dilution rate }\end{array}$ &
\end{tabular}

It is worth noting that, besides extracellular $\beta$-galactosidase production, ethanol production close to the expected theoretical values [17] was obtained (Fig. 1). For this system, the maximum ethanol productivity, $9 \mathrm{~g} / \mathrm{l} \mathrm{h}$, was slightly lower than that obtained with the recombinant strain $S$. cerevisiae NCYC869-A3/T1 [10] although higher than the reported for conventional systems.

As for batch experiments a two-fold increase in supernatant $\beta$-galactosidase activity was observed when the lactose initial concentration was increased from 50 to $100 \mathrm{~g} / \mathrm{l}$ [13], continuous operation of the bioreactor fed with a $100 \mathrm{~g} / \mathrm{l}$ initial lactose concentration was assayed. However, for the tested dilution rates the extracellular $\beta$-galactosidase concentration decreased continuously with increase in dilution rate (Fig. 2). Once more, the decrease in $\beta$-galactosidase activity occurred simultaneously with an increase in the reducing sugars concentration in the fermentation broth (Table 2). Even though cell viability was always above $90 \%$, an increase in the biomass concentration in the effluent was observed for dilution rates higher than $0.15 \mathrm{~h}^{-1}$.

After $\beta$-galactosidase activity in the fermentation broth reached a value that makes the lactose hydrolysis rate higher than the rate of glucose and galactose metabolism,

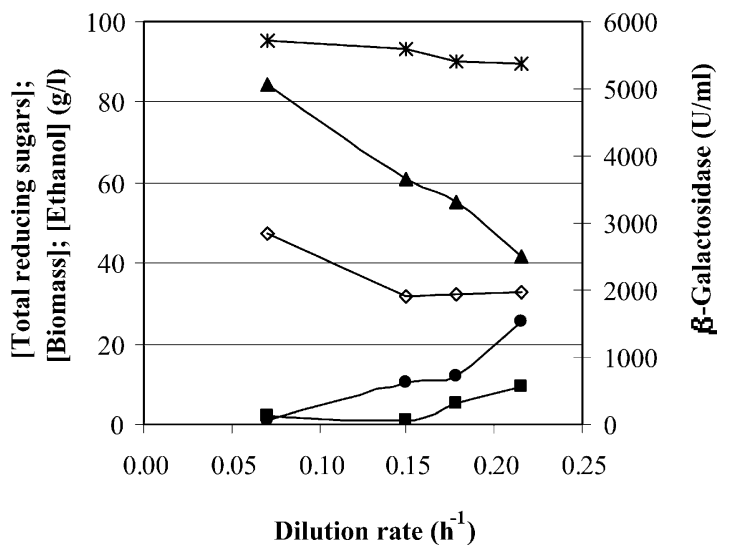

Fig. 2. Variation of biomass concentration in the effluent ( $\square$ ), total reducing sugars $(\boldsymbol{O})$, ethanol $(\diamond)$ concentration, $\beta$-galactosidase activity (A) and cell viability $(*)$ with dilution rate for continuous operation with SSlactose medium (100 g/l lactose). 
Table 2

Glucose, galactose and lactose concentrations at different dilution rates for the continuous operation fed with $100 \mathrm{~g} / \mathrm{l}$ initial lactose concentration

\begin{tabular}{llll}
\hline Dilution rate $\left(\mathrm{h}^{-1}\right)$ & Glucose $^{\mathrm{a}}(\mathrm{g} / \mathrm{l})$ & Galactose $^{\mathrm{a}}(\mathrm{g} / \mathrm{l})$ & Lactose $^{\mathrm{a}}(\mathrm{g} / \mathrm{l})$ \\
\hline 0.07 & 0.1 & 0.2 & 0.0 \\
0.15 & 2.9 & 5.3 & 0.0 \\
0.18 & 2.6 & 5.9 & 1.8 \\
0.22 & 8.1 & 11.3 & 7.2 \\
\hline
\end{tabular}

a Values correspond to measurements made at five residence times for each dilution rate.

sugar accumulation in the culture broth occurs and the percentage of $\beta$-galactosidase producing cells decreases (for the $0.18 \mathrm{~h}^{-1}$ dilution rate only $35 \%$ of the yeast cells in the bioreactor were producing $\beta$-galactosidase). In spite of this reduction of $\beta$-galactosidase producing cells a four-fold increase in $\beta$-galactosidase productivity (Table 1) was observed at this dilution rate when compared to batch culture with the same medium (100 g/l initial lactose concentration).

\section{Conclusions}

For economic reasons, it is important to maximise protein production by genetic means or/and microbial process development. This can be achieved by increasing the amount of protein per cell per time and/or by increasing cell concentration per time [18]. In this work, the feasibility of using flocculent continuous high-cell-density systems for higher extracellular protein production has been shown, being achieved an increase in $\beta$-galactosidase productivity (4-11-fold increase) when compared to batch cultures for the same substrate concentration. Moreover, the purification steps are greatly simplified as cells are easily separated from the culture broth. Even though for batch cultures with a $100 \mathrm{~g} / \mathrm{l}$ initial lactose concentration a two-fold increase in $\beta$-galactosidase productivity was observed when compared to a $50 \mathrm{~g} / \mathrm{l}$ initial lactose concentration, the same was not observed in continuous high-cell-density culture. A decrease on the number of $\beta$-galactosidase producing cells was observed when the rate of lactose hydrolysis by the secreted $\beta$-galactosidase was higher than the rate of metabolism of glucose and galactose.

The developed system is particularly attractive for application in the dairy industry. Besides producing extracellular $\beta$-galactosidase that can be easily separated from the culture broth, the recombinant $S$. cerevisiae strain also presented high ethanol productivity $(9 \mathrm{~g} / \mathrm{l} \mathrm{h})$.

The feasibility of using continuous high-cell-density systems with flocculent yeast cells for the extracellular production of heterologous proteins has been proved. Up to now these systems have been mainly studied for the production of ethanol [19].

\section{References}

[1] Neelakantan S, Mohanty AK, Kaushik JK. Production and use of microbial enzymes for dairy processing. Curr Sci 1999;77: 143-9.

[2] Shukla TP. Beta-galactosidase technology: a solution to the lactose problem. CRC Crit Rev Food Technol 1975;5:325-56.

[3] Dziezak, JD. Enzymes: catalysts for food processes. Food Technol 1991;January:78-85.

[4] Godfrey, T. Developments in speciality enzymes. World Food Ingredients 2000;February/March:30-5.

[5] Lifran EV, Hourigan JA, Sleigh RW, Johnson RL. New wheys for lactose. Food Aust 2000;52:120-5.

[6] Gekas V, López-Leiva M. Hydrolysis of lactose: a literature review. Process Biochem 1985;20:2-12.

[7] Holsinger VH, Kligerman AE. Applications of lactase in dairy foods and other foods containing lactose. Food Technol 1991;January:92-5.

[8] Sarney DB, Hale C, Frankel G, Vulfson EN. A novel approach to the recovery of biologically active oligosaccharides from milk using a combination of enzymatic treatment and nanofiltration. Biotechnol Bioeng 2000;69:461-7.

[9] Domingues L, Teixeira JA, Lima N. Construction of a flocculent Saccharomyces cerevisiae fermenting lactose. Appl Microbiol Biotechnol 1999;51:621-6.

[10] Domingues L, Dantas MM, Lima N, Teixeira JA. Continuous ethanol fermentation of lactose by a recombinant flocculating Saccharomyces cerevisiae strain. Biotechnol Bioeng 1999;64:692-7.

[11] Domingues L, Lima N, Teixeira JA. Alcohol production from cheese whey permeate using genetically modified yeast cells. Biotechnol Bioeng 2001;72:507-14.

[12] Domingues L, Lima N, Teixeira JA. On the contamination of flocculating yeast high cell density continuous bioreactor. Biotechnol Bioeng 2000;68:584-7.

[13] Domingues L, Teixeira JA, Penttilä M, Lima N. Construction of a flocculent Saccharomyces cerevisiae strain secreting high levels of Aspergillus niger $\beta$-galactosidase. Appl Microbiol Biotechnol 2002;58:645-50.

[14] Miller GL. Use of dinitrosalicilic acid reagent for determination of reducing sugar. Anal Chem 1959;31:426-8.

[15] Shu C-H, Yang S-T. Kinetics of continuous GM-CSF production by recombinant Saccharomyces cerevisiae in an airlift bioreactor. J Biotechnol 1996;48:107-16.

[16] Giuseppin MLF, Almrek JW, Heistek JC, Verrips CT. Comparative study on the production of guar $\alpha$-galactosidase by Saccharomyces cerevisiae SU50b and Hansenula polymorpha 8/2 in continuous cultures. Appl Environ Microbiol 1993;59:52-9.

[17] Bailey JE, Ollis DF. Biochemical engineering fundamentals. 2nd ed. McGraw-Hill International Editions; 1986.

[18] Wilms B, Hauck A, Reuss M, Syldatk C, Mattes R, Siemann M, et al. High-cell-density fermentation for production of L- $N$-Carboamylase using an expression system based on the Escherichia coli rhaBAD promoter. Biotechnol Bioeng 2001;73:95-103.

[19] Domingues L, Vicente AA, Lima N, Teixeira JA. Applications of yeast flocculation in biotechnological processes. Biotechnol Bioprocess Eng 2000;5:288-305. 